\title{
The influence of different culture microenvironments on the generation of dendritic cells from non-small-cell lung cancer patients
}

\author{
Paweł Krawczyk ${ }^{1}$, Kamila Wojas ${ }^{2}$, Janusz Milanowski ${ }^{1}$ and Jacek Roliński ${ }^{2}$ \\ ${ }^{1}$ Department of Pneumology, Oncology and Allergology, Medical University of Lublin, Poland \\ 2 Clinical Immunology Department, Medical University of Lublin, Poland
}

Received: 2007.06.05, Accepted: 2007.10.25, Published online first: 2007.12.03

\begin{abstract}
Introduction: Monocyte-derived dendritic cells (DCs) are currently under extensive evaluation as cell vaccines for cancer treatment. Many protocols regarding DCs generation in vitro with different protein components, especially autologous proteins, have been described. On the other hand, active tumor-derived factors in patients' serum could impair monocytes, which might result in their abrogated differentiation into DCs in vitro.

Materials and Methods: Autologous DCs from non-small-cell lung cancer (NSCLC)-bearing patients were generated in different culture microenvironments. Peripheral blood mononuclear cells (PBMCs) were cultured in the presence of interleukin-4 and granulocyte-monocyte-stimulating factor with supplementation of $10 \%$ autologous serum, $10 \%$ allogenic serum, or $2 \%$ human albumin. The course of apoptosis, phagocytic ability, and the immunophenotype of the generated DCs were analyzed using flow cytometric methods.

Results: After $48 \mathrm{~h}$ of culture, we found a lower percentage of $\mathrm{CD}^{+}{ }^{+} / \mathrm{CD} 14^{+}$and a higher percentage of $\mathrm{CD} 1 \mathrm{a}^{+} / \mathrm{CD} 14^{-}$cells in the culture supplemented with human albumin than in the cultures supplemented with serums. The lowest CD14 antigen expression was found in the human albumin-supplemented 48-h cultures. After $48 \mathrm{~h}$ in the cultures carried out with human albumin we found significantly higher percentages of $\mathrm{AV}^{+} / \mathrm{PI}^{+}$cells and $\mathrm{AV}^{-} / \mathrm{PI}^{+}$cells than in cultures supplemented with autologous or allogenic serum. We also noted that the expression of FITC-dextran after 4 and $24 \mathrm{~h}$ of incubation was significantly higher in the cultures supplemented with both serums than in the HA-SC. The percentage of semi-mature DCs and of CD83 expression was lowest in the culture supplemented with $2 \%$ human albumin.

Conclusions: The kind of culture supplementation had a great impact on the apoptosis of cultured PBMCs. It could also influence the yield of monocyte-derived DCs. It was also confirmed that autologous and allogenic serums provide suitable microenvironments for the generation of autologous DCs from NSCLC patients. The choice of culture supplementation for DC generation is still unsolved and further studies should be undertaken.
\end{abstract}

Key words: dendritic cells, non-small-cell lung cancer, immunophenotyping, cell culture.

Abbreviations: AlloS-SC - allogenic serum-supplemented culture, APC - antigen-presenting cell, AutoS-SC - autologous serum-supplemented culture, AV - annexin V, DCs - dendritic cells, FCS - fetal calf serum, HA-SC - human albumin-supplemented culture, NSCLC - non-small-cell lung cancer, PBMCs - peripheral blood mononuclear cells, PI - propidium iodide, IL-4 - interleukin-4, PBS - phosphate-buffered saline.

Corresponding author: Paweł Krawczyk, M.D. Ph.D., Department of Pneumology, Oncology and Allergology Medical University of Lublin, Jaczewskiego 8, 20-950 Lublin, Poland, tel.: +48 81 724-48-39, fax: +48 81 724-48-23, e-mail: pulm. dept@am.lublin.pl

\section{INTRODUCTION}

Lung cancer has the highest mortality rate amongst men and women in western countries [4, 47]. Non-small-cell lung cancer (NSCLC), which includes adenocarcinoma, squamous cell carcinoma, and giant cell carcinoma, comprises the majority of cases and is refractory to conventional therapeutic modalities [4, 19, 47]. About $50 \%$ of NSCLC patients have stage IV disease at the time of diagnosis and their median survival rate seldom exceeds 6-9 months [19]. What is more, stages IIIB and IV, which preclude surgical therapy, account for $70 \%$ of all cases. Chemotherapy and radiotherapy applied to that type of cancer are of low efficacy $[4,19,24,48]$. The 
lack of a standard therapy has prompted study of the development of novel therapies for the treatment of NSCLC. One of them is the administration of drugs that suppress neoplastic cell proliferation by inhibition of the epidermal growth factor receptor; another consists of immunotherapy using unspecific factors that stimulate the immune system, such as BCG vaccine, cytokines which modulate the immunological response, neoplastic antigens, and immune system cells [4, 19, 47]. There have been many attempts to treat NSCLC patients with cellular therapies, such as lymphokine-activated killer cells or tumor-infiltrating lymphocytes, although results have not been encouraging [4, 47, 50].

The discovery of dendritic cells (DCs) as professional antigen-presenting cells (APCs) opened up new possibilities for their use in the development of cancer vaccines $[10,17,20,28,38,41,49]$. The principal purpose of DC-based immunotherapy is to induce an antigen-specific immune response [20,38]. The effector arm of anti-tumor immunity are $\mathrm{CD} 4^{+}$and $\mathrm{CD} 8^{+}$cells, which can only recognize antigen when it is presented by APCs [17, $26,38]$. Owing to their unique properties, DCs, which are the most potent APCs, are considered attractive adjuvants in such immunotherapy $[30,38]$. The preparation of a DCs vaccine comprises of the generation of DCs from $\mathrm{CD} 34^{+}$precursor cells or monocytes, loading the generated DCs with specific tumor antigens and, finally, administration of the vaccine to the patient $[10,26,30$, 41]. Upon administration, the DCs should migrate to secondary lymphoid organs and induce an antigen-specific immune response $[17,30]$. DC-based cancer vaccines are used in patients with melanomas, myelomas, prostate cancers, renal cancers, breast cancers, ovarian cancers, and gastrointestinal cancers [10, 20, 26, 28, 38].

It is well known that in tumor-bearing hosts the immune system frequently does not react to the tumors $[8,15,32,45]$. The tumoral microenvironment is usually referred to as a "black hole", where the mechanisms which impair immune responses are not clearly identified $[6,18,26,32]$. Clinical observations showed that DCs possess the ability to migrate directly to a neoplastic site, but it is still not clear why they are unable to induce an efficient immune response [37, 42]. A growing body of evidence suggests that autologous DCs in a cancer-bearing host are not fully competent, which could account for the decreasing, or even obstructive, efficiency of vaccination [10, 18, 22, 23, 26, 31]. How strongly could tumor-derived factors inhibit the host immune system?

With the above problems in mind, the aim of the present study was to verify the ability to generate in vitro DCs from NSCLC patients. The cultures were prepared with an addition of $10 \%$ autologous serum from the patients to create a microenvironment resembling the in vivo appearance [12]. DCs were also generated in medium supplemented with $2 \%$ human albumin to avoid the possible inhibitory effect of the tumor microenvironment [2]. Additionally, a generation with healthy human serum was cultured to establish the influence of physio- logical serum on DCs cultures. These methodologies could be conducive to improving the methods of generating autologous DCs from NSCLC patients and to adopting them in future immunotherapy.

\section{MATERIALS AND METHODS}

\section{Clinical characteristic of the lung cancer patients}

The study population comprised of 14 NSCLC subjects (mean age: $61.75 \pm 9.92$ years). Confirmation of the histopathologic type of lung cancer was obtained for all patients. Laboratory tests, chest X-rays, computed tomography, ultrasonography, and bronchoscopy were used for the evaluation of the lung cancer stage and type of disease manifestation (Table 1). Stages from I to IIIA were specified as local disease, whereas stages IIIB and IV were specified as generalized lung cancer. Owing to the small number of examined patients, this division was applied in the statistical analysis [1].

\section{Preparation of serum}

Autologous serum was obtained by centrifugation (3000 rpm/10 min.) of peripheral blood samples taken from each patient, which were then frozen in aliquots (10 aliquots of $1 \mathrm{ml}, 4$ aliquots of $200 \mu \mathrm{l}$ ) at $80^{\circ} \mathrm{C}$ and successively thawed when examined. Allogenic serum obtained from 14, only $\mathrm{AB}$ healthy volunteers served as controls. The serums were not mixed. The serum samples was used to supplement the culture medium and for cytokine measurement using ELISA.

\section{Generation of DCs}

Peripheral blood was drawn from NSCLC patients into heparinized tubes according to the protocols accepted by the local ethics committee. Peripheral blood mononuclear cells (PBMCs) were isolated by density gradient centrifugation (Lymphoprep, Nycomed, Norway). Total mononuclear cell counts oscillated between 33 and 54 millions cells. After isolation, the PBMCs were resuspended in RPMI 1640 medium (BioWhittaker, Belgium) supplemented with penicillin-streptomycin (1\% v/v, Sigma, Germany), seeded in 6-well tissue culture plates in an appropriate culture microenvironment, and left to adhere for $1.5 \mathrm{~h}$ at $37^{\circ} \mathrm{C}$ in a humidified $5 \% \mathrm{CO}_{2}$ atmosphere. The following culture systems were carried out: 1 ) human albuminsupplemented cultures (HA-SC): PBMCs from patients in medium containing $2 \%$ human albumin [2]; 2) autologous serum-supplemented culture (AutoS-SC): PBMCs from patients in medium containing $10 \%$ autologous serum; 3) allogenic serum-supplemented culture (AlloS-SC): PBMCs from patients in medium containing $10 \%$ allogenic serum from a healthy donor. After the adherence time, non-adherent cells were removed and the culture plates were washed with cold phosphate- 
Table 1. Clinical characteristic of examined patients

\begin{tabular}{|c|c|c|c|c|c|c|c|c|}
\hline No. & $\begin{array}{c}\text { Age } \\
\text { (years) }\end{array}$ & Gender & Disease & TNM & Stage & Localization & Prospects & Leukocyte count \\
\hline 1 & 51 & M & $\mathrm{SCC}$ & $\mathrm{T}_{4} \mathrm{~N}_{3} \mathrm{M}_{1}$ & IV & right, central & death & above normal \\
\hline 2 & 50 & M & SCC & $\mathrm{T}_{2} \mathrm{~N}_{0} \mathrm{M}_{0}$ & I & right, central & chemotherapy & normal \\
\hline 3 & 65 & M & $\mathrm{SCC}$ & $\mathrm{T}_{3} \mathrm{~N}_{2} \mathrm{M}_{0}$ & IIIA & left, central & chemotherapy & normal \\
\hline 4 & 53 & M & $\mathrm{AC}$ & $\mathrm{T}_{4} \mathrm{~N}_{2} \mathrm{M}_{1}$ & IV & left, central & death & normal \\
\hline 5 & 58 & M & SCC & $\mathrm{T}_{2} \mathrm{~N}_{1} \mathrm{M}_{0}$ & II & left, central & surgery & above normal \\
\hline 6 & 75 & M & SCC & $\mathrm{T}_{3} \mathrm{~N}_{2} \mathrm{M}_{0}$ & IIIA & left, central & surgery & above normal \\
\hline 7 & 53 & $\mathrm{~F}$ & other* & $\mathrm{T}_{3} \mathrm{~N}_{3} \mathrm{M}_{0}$ & IIIB & right, peripheral & death & normal \\
\hline 8 & 70 & M & $\mathrm{AC}$ & $\mathrm{T}_{4} \mathrm{~N}_{2} \mathrm{M}_{0}$ & IIIB & left, central & chemotherapy & normal \\
\hline 9 & 76 & M & other $* *$ & $\mathrm{~T}_{4} \mathrm{~N}_{2} \mathrm{M}_{0}$ & IIIB & right, central & chemotherapy & above normal \\
\hline 10 & 78 & M & other** & $\mathrm{T}_{4} \mathrm{~N}_{3} \mathrm{M}_{0}$ & IIIB & right, peripheral & chemotherapy & normal \\
\hline 11 & 62 & M & $\mathrm{SCC}$ & $\mathrm{T}_{4} \mathrm{~N}_{1} \mathrm{M}_{0}$ & IIIB & right, central & chemotherapy & above normal \\
\hline 12 & 70 & M & GCC & $\mathrm{T}_{2} \mathrm{~N}_{1} \mathrm{M}_{0}$ & II & left, peripheral & surgery & normal \\
\hline 13 & 63 & M & SCC & $\mathrm{T}_{4} \mathrm{~N}_{3} \mathrm{M}_{0}$ & IIIB & left, central & chemotherapy & above normal \\
\hline 14 & 67 & M & SCC & $\mathrm{T}_{3} \mathrm{~N}_{1} \mathrm{M}_{0}$ & IIIA & left, central & surgery & normal \\
\hline
\end{tabular}

SCC - squamous cell carcinoma, AC - adenocarcinoma, GCC - giant cell carcinoma, other - including *low-differentiated NSCLC and **unclassified NSCLC, TNM - classification of tumors [4].

-buffered saline (PBS) without $\mathrm{Ca}^{2+}$ and $\mathrm{Mg}^{2+}($ Biochrom AG, Germany) to obtain a pure fraction of adherent $\mathrm{CD}_{14}{ }^{+}$monocytes. The adherent cells were then cultured in an appropriate medium supplemented with recombinant human interleukin (IL)-4 (500 IU/ml, Strathmann, Germany) and recombinant human granulocyte-monocyte-stimulating factor $(1000 \mathrm{IU} / \mathrm{ml}$, Gentaur, Belgium). The cells were fed every three days. On the 5th day, recombinant human tumor necrosis factor $\alpha(50 \mathrm{ng} / \mathrm{ml}$, Strathmann, Germany) was added to induce terminal maturation of the generated DCs. On day 7, at the end of the culture, the supernatants were collected and the adherent cells were harvested by incubation with a trypsin/EDTA solution $(0.25 \% / 0.02 \%$, Biochrom AG, Germany). The obtained mature DCs were washed in PBS without $\mathrm{Ca}^{2+}$ and $\mathrm{Mg}^{2+}$ and resuspended prior to immunophenotyping. The yield of cultured DCs was 3-4\% of the initial PBMC counts.

\section{Phagocytosis assay}

To measure the phagocytic activity of the generated DCs, 5-day cultures in the aforementioned systems were also carried out. At the end of the culture, the generated immature DCs were resuspended in RPMI 1640 and incubated with FITC-dextran (ICN, Germany) at a concentration of $1 \mathrm{mg} / \mathrm{ml}$ of medium at $37^{\circ} \mathrm{C}$ for 4 and $24 \mathrm{~h}$ and at $4^{\circ} \mathrm{C}$ for $4 \mathrm{~h}$. The incubations were stopped by adding cold RPMI 1640 . The cells were washed twice with cold RPMI 1640 and immediately analyzed by flow cytometry.

\section{Apoptosis analysis in the course of the cell cultures}

For quantification of the cells undergoing early programmed cell death, an annexin $\mathrm{V}(\mathrm{AV})$ and propidium iodide (PI) apoptosis detection kit (R\&D, USA) was utilized according to the manufacture's protocol. The cells were cultured in the above systems and then removed from the culture plates after 48 and $96 \mathrm{~h}$ of incubation. Freshly isolated PBMCs were also examined. The cells were washed with PBS without $\mathrm{Ca}^{2+}$ and $\mathrm{Mg}^{2+}$ and resuspended in the binding buffer provided. AV (FITC-conjugated) and specific monoclonal antibodies (anti-CD14 TC-conjugated and anti-CD1a PE-conjugated, Caltag, USA) were added. The cells were incubated for $15 \mathrm{~min}$ at room temperature in the dark. PI was added in the last $5 \mathrm{~min}$ of incubation to the tubes containing only $\mathrm{AV}$; then the cells were analyzed by flow cytometry.

\section{Immunophenotyping of generated DCs}

To characterize the phenotype of the generated DCs, the following panel of FITC-, PE-, and TC-conjugated monoclonal antibodies (Caltag, USA) was used: isotype control mouse anti-human IgG1/IgG2/IgG2a, mouse anti-human CD45/CD14, mouse anti-human CD83/CD1a/HLA-DR, and mouse anti-human CD80/ /CD86/HLA-DR.

The cells were incubated for $20 \mathrm{~min}$ in the dark and then washed in PBS without $\mathrm{Ca}^{2+}$ and $\mathrm{Mg}^{2+}$. The cells were analyzed using a FACSCalibur flow cytometer (Becton Dickinson, USA) equipped with a 488-nm argon laser. An acquisition gate was established based on forward scatter (FSC) and side scatter (SSC) that included only the monocyte population (mononuclear cells) and excluded lymphocytes. After acquisition, the cells were analyzed with CellQuest Software.

\section{ELISA analysis of IL-10 level in the patients' serum}

The level of IL-10 was measured in the patients' serum using the Quantikine HS Human IL-10 ELISA Kit (R\&D Systems, USA) and $E_{X} 800$ equipment (BioTek Instruments, USA). 


\section{Statistical analysis}

The data are presented as the mean value \pm SD. To evaluate the statistical significance, the Mann-Whitney U-test was used to compare unpaired group data. The Wilcoxon matched pairs test was applied for comparing two variables. We also applied the non-parametric Kolmogorow-Smirnow test to compare the two groups. The Spearman correlation test was used for correlating observations. A level of $\mathrm{p}<0.05$ was considered significant.

\section{RESULTS}

The influence of culture supplementation on the expressions of CD1a and CD14 antigens as well as cell apoptosis

In this investigation the cell population was analyzed using an assay for phosphatidylserine expression as originally developed by Vermes et al. [44]. We defined early apoptotic cells as $\mathrm{AV}^{+} / \mathrm{PI}^{-}$, late apoptotic cells and necrotic cells as $\mathrm{AV}^{+} / \mathrm{PI}^{+}$, and dead cells as $\mathrm{AV}^{-} / \mathrm{PI}^{+}$. A representative cytometric analysis is shown in Fig. 1.

After $48 \mathrm{~h}$ of culture, we found a significantly $(\mathrm{p}<0.05)$ lower percentage of $\mathrm{CD} 1 \mathrm{a}^{+} / \mathrm{CD} 14^{+}$cells in the culture supplemented with human albumin than in the cultures supplemented with autologous or allogenic serum. Moreover, in the culture with human albumin we found a significantly $(\mathrm{p}<0.05)$ higher percentage of $\mathrm{CD} \mathrm{a}^{+} / \mathrm{CD} 14^{-}$cells than in the cultures carried out with the addition of autologous or allogenic serum (Table 2).

The expression of CD14 antigen was significantly higher on freshly isolated cells than on cells cultured in all types of medium. In the 96-h cultures a small population of cells, resembling macrophages, with a high expression of CD14 antigen and high values of the FSC and SSC parameters, appeared. These macrophage-like cells were also found at the end of the DC generation (Fig. 2). The lowest CD14 antigen expression was found in the human albumin-supplemented 48-h cultures. A significant $(\mathrm{p}<0.05)$ increase in CD1a antigen expression was observed between 48 and $96 \mathrm{~h}$ in all cultures.

After $48 \mathrm{~h}$ of culture, the percentage of $\mathrm{AV}^{+}$cells among the populations of $\mathrm{CD} 1 \mathrm{a}^{+} / \mathrm{CD} 14^{+}$cells and $\mathrm{CD} \mathrm{a}^{+} / \mathrm{CD} 14^{-}$cells was significantly higher in the HA-SCs than in the autologous or AlloS-SC. More interestingly, in the cultures carried out with human albumin we found significantly higher percentages of $\mathrm{AV}^{+} / \mathrm{PI}^{+}$cells and $\mathrm{AV}^{-} / \mathrm{PI}^{+}$cells than in cultures supplemented with autologous or allogenic serum (Table 2, Fig. 3).

In HA-SC after $96 \mathrm{~h}$ of incubation we found a significantly higher percentage of $\mathrm{AV}^{+}$cells amongst $\mathrm{CD} \mathrm{a}^{+} / \mathrm{CD} 14^{+}$and $\mathrm{CD} 1 \mathrm{a}^{+} / \mathrm{CD} 14^{-}$cell populations in comparison with AutoS-SC and AlloS-SC. We also noted a significantly higher percentage of $\mathrm{AV}^{+} / \mathrm{PI}^{+}$cells in culture supplemented with human albumin compared with the two other culture systems.
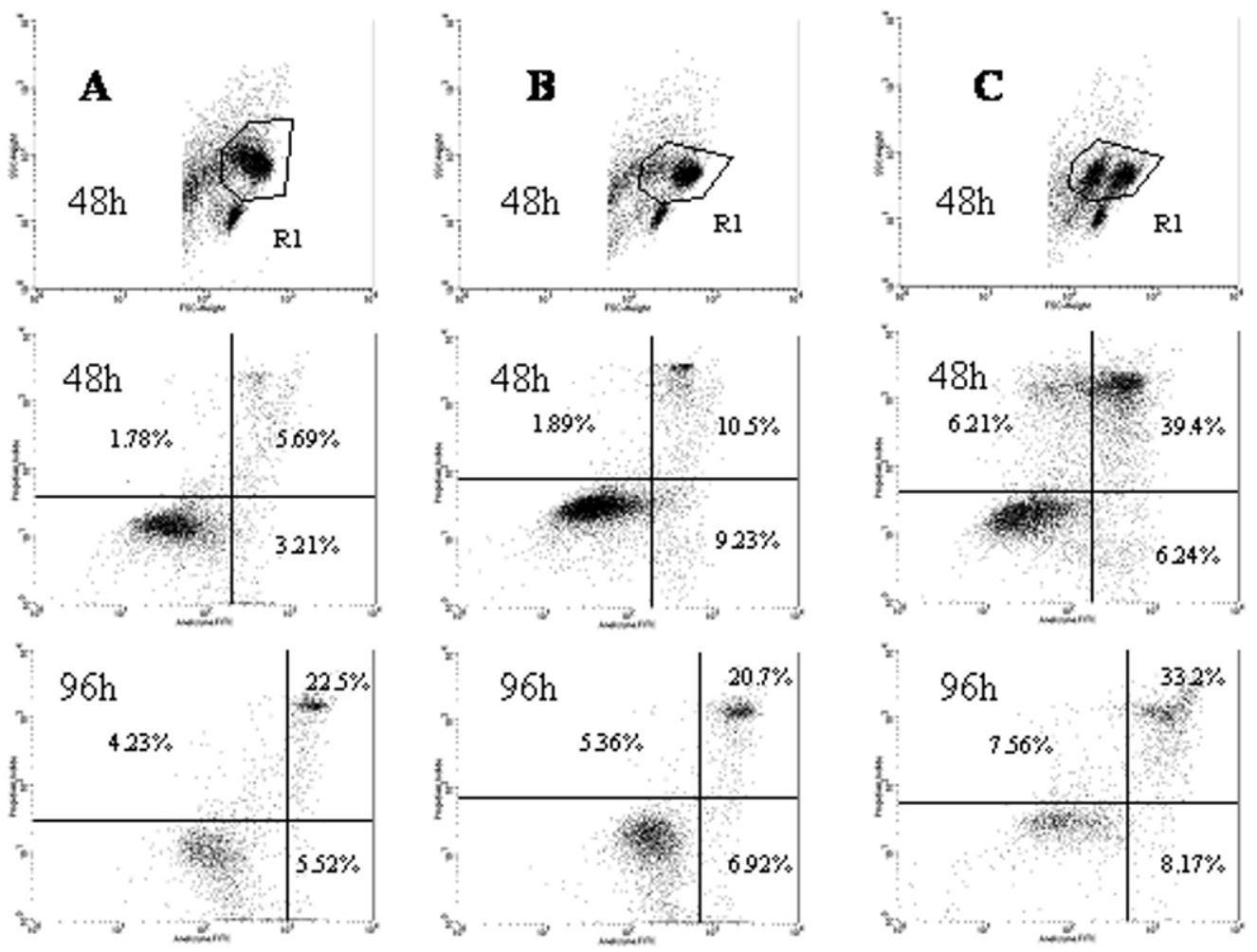

Fig. 1. Representative cytometry analysis of AV and PI expression on generated mononuclear cells after 48 and 96 h of incubation. A - culture supplemented with autologous serum, B - culture supplemented with allogenic serum, $\mathbf{C}-$ culture supplemented with human albumin. Dot plots correspond to the gated cells from region $\mathrm{R} 1$. 
Table 2. Characteristics of cells generated before culture and after $48 \mathrm{~h}$ and $96 \mathrm{~h}$ of culture supplemented with autologous serum, allogenic serum, and human albumin

\begin{tabular}{lccccccc}
\hline \multirow{2}{*}{$\begin{array}{l}\text { Percentage of } \\
\text { generated cells }\end{array}$} & Before culture & \multicolumn{2}{c}{ Autologous serum } & \multicolumn{2}{c}{ Allogenic serum } & \multicolumn{2}{c}{ Human albumin } \\
\cline { 2 - 7 } & & $48 \mathrm{~h}$ & $96 \mathrm{~h}$ & $48 \mathrm{~h}$ & $96 \mathrm{~h}$ & $48 \mathrm{~h}$ & $96 \mathrm{~h}$ \\
\hline${\mathrm{CD} 1 \mathrm{a}^{+} / \mathrm{CD} 14^{+}}^{7}$ & $79.72 \pm 15.33$ & $87.67 \pm 8.83$ & $84.66 \pm 13.69$ & $88.84 \pm 9.15$ & $82.48 \pm 15.2$ & $79.45 \pm 8.38$ & $76.02 \pm 22.07$ \\
$\mathrm{CD} 1 \mathrm{a}^{+} / \mathrm{CD} 14^{-}$ & $7.07 \pm 7.13$ & $7.57 \pm 7.44$ & $8.22 \pm 8.37$ & $6.7 \pm 4.43$ & $10.74 \pm 10.54$ & $13.46 \pm 6.5$ & $15.01 \pm 17.29$ \\
$\mathrm{AV}^{+} / \mathrm{CD} 1 \mathrm{a}^{+} / \mathrm{CD} 14^{+}$ & $3.59 \pm 2.13$ & $25.55 \pm 8.35$ & $33.95 \pm 23.36$ & $25.68 \pm 13.93$ & $32.06 \pm 22.16$ & $43.6 \pm 16.36$ & $49.9 \pm 18.84$ \\
$\mathrm{AV}^{+} / \mathrm{CD} 1 \mathrm{a}^{+} / \mathrm{CD} 14^{-}$ & $2.5 \pm 1.54$ & $28.54 \pm 12.99$ & $18.82 \pm 13.56$ & $27.95 \pm 14.1$ & $20.02 \pm 7.5$ & $49.8 \pm 14.8$ & $39.8 \pm 18.4$ \\
$\mathrm{AV}^{+} / \mathrm{PI}^{-}$ & $0.64 \pm 1.0$ & $8.49 \pm 5.93$ & $6.58 \pm 5.43$ & $10.13 \pm 9.24$ & $7.93 \pm 4.73$ & $6.35 \pm 4.31$ & $9.14 \pm 5.03$ \\
$\mathrm{AV}^{+} / \mathrm{PI}^{+}$ & $2.16 \pm 1.72$ & $12.33 \pm 7.79$ & $24.04 \pm 12.07$ & $12.79 \pm 8.96$ & $22.8 \pm 9.94$ & $40.62 \pm 15.8$ & $35.34 \pm 12.9$ \\
$\mathrm{AV}^{-} / \mathrm{PI}^{+}$ & $2.19 \pm 0.78$ & $2.97 \pm 2.86$ & $6.88 \pm 3.74$ & $2.42 \pm 2.26$ & $11.19 \pm 8.56$ & $6.5 \pm 3.77$ & $9.68 \pm 9.31$ \\
$\mathrm{MFI} \mathrm{CD14}$ & $681 \pm 454$ & $151.1 \pm 64.27$ & $206.14 \pm 181.1$ & $152.18 \pm 66.8$ & $146.03 \pm 82.9$ & $73.63 \pm 39.3$ & $132.05 \pm 91.46$ \\
$\mathrm{MFI} \mathrm{CD} 1 \mathrm{a}$ & $98.8 \pm 70.65$ & $64.9 \pm 13.98$ & $118.41 \pm 64.6$ & $68.8 \pm 16.17$ & $110.7 \pm 42.4$ & $68.32 \pm 33.84$ & $139.98 \pm 98.6$ \\
\hline
\end{tabular}

MFI - mean fluorescence intensity.

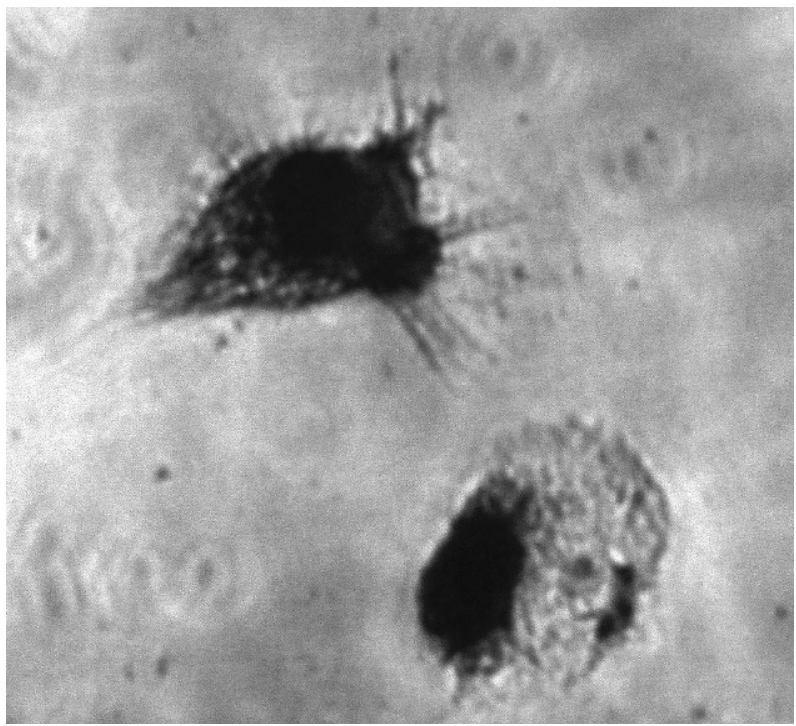

Fig. 2. Macrophage-like cells and DCs generated after 7-day culture supplemented with $10 \%$ autologous serum. The cells were stained by the May-Grünwald Giemsa method.

We did not find any significant differences in the examined parameters between the cultures supplemented with autologous serum and allogenic serum after 48 and $96 \mathrm{~h}$ of incubation. The percentages of cells generated in all the cultures are shown in Table 2 and Fig. 3.

Relationship between cancer stage and the expressions of CD1a and CD14 antigens as well as cell apoptosis in differently supplemented cultures

After $96 \mathrm{~h}$ of incubation in AutoS-SC and AlloS-SC, a significantly higher percentage of double-positive $\mathrm{CD} 1 \mathrm{a}^{+} / \mathrm{CD} 14^{+}$cells and lower percentage of $\mathrm{CD} 1 \mathrm{a}^{+} /$ $/ \mathrm{CD} 14^{-}$cells were found in patients with advanced disease than in subjects suffering from earlier stages of lung cancer. Interestingly, a significantly lower percentage of $\mathrm{AV}^{+} / \mathrm{PI}^{+}$and $\mathrm{AV}^{+} / \mathrm{PI}^{-}$cells were detected in patients with advanced stages of lung cancer than in

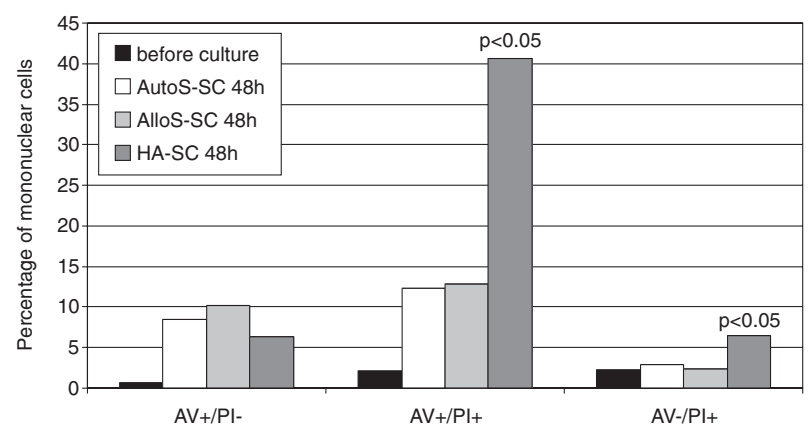

Fig. 3. Percentages of apoptotic, late apoptotic, and necrotic cells before and after $48 \mathrm{~h}$ of culture in different microenvironments.

patients with local tumor growth. The percentages of examined cells were similar in both groups of patients in the cultures performed with human albumin.

There were significant negative correlations between the percentages of $\mathrm{CD}_{1}{ }^{+} / \mathrm{CD} 14^{-}$cells and $\mathrm{AV}^{+} / \mathrm{PI}^{-}$ cells in AutoS-SC and AlloS-SC after 48 and $96 \mathrm{~h}$ of incubation in all the patients $(\mathrm{R}=-0.70, \mathrm{p}<0.05)$. Also, after $96 \mathrm{~h}$ of incubation in AutoS-SC the percentages of $\mathrm{CD} 1 \mathrm{a}^{+} / \mathrm{CD} 14^{-}$cells and of $\mathrm{AV}^{+} / \mathrm{PI}^{-}$cells correlated significantly negatively with patient leukocytosis.

Serum IL-10 level and its influence on the expressions of CD1a and CD14 antigens and cell apoptosis

The total mean level of IL-10 in the patients' serum was $6.57 \pm 3.51 \mathrm{pg} / \mathrm{ml}$. Serum IL-10 level was significantly higher $(\mathrm{p}=0.01)$ in NSCLC patients than in control subjects $(2.957 \pm 2.177 \mathrm{pg} / \mathrm{ml})$. The IL-10 concentration was similar in patients with different clinical stages of the disease.

After $48 \mathrm{~h}$ of culture with autologous serum supplementation we found a significant negative correlation between the percentage of $\mathrm{CD} 1 \mathrm{a}^{+} / \mathrm{CD} 14^{+}$cells and the level of IL-10 ( $\mathrm{R}=-0.69, \mathrm{p}<0.05)$. We also noted positive correlation between the IL-10 level and the percentage of $\mathrm{CD}^{1} \mathrm{a}^{+} / \mathrm{CD} 14^{-}$cells $(\mathrm{R}=0.69, \mathrm{p}<0.05)$. The 
Table 3. Expression of FITC-dextran phagocytozed by immature DCs cultured with autologous serum, allogenic serum, and human albumin supplemented cultures

\begin{tabular}{lccc}
\hline Culture microenvironment & Cells incubated at $4{ }^{\circ} \mathrm{C}$ & Cells incubated at $37^{\circ} \mathrm{C}$ for $4 \mathrm{~h}$ & Cells incubated at $37^{\circ} \mathrm{C}$ for $24 \mathrm{~h}$ \\
\hline $10 \%$ Autologous serum & $15.1 \pm 10 \mathrm{MFI}$ & $28.29 \pm 11.95 \mathrm{MFI}$ & $37.39 \pm 17.4 \mathrm{MFI}$ \\
$10 \%$ Allogenic serum & $15.55 \pm 12.92 \mathrm{MFI}$ & $25.47 \pm 11.7 \mathrm{MFI}$ & $38.02 \pm 18.72 \mathrm{MFI}$ \\
$2 \%$ Human albumin & $18.78 \pm 22.56 \mathrm{MFI}$ & $20.69 \pm 9.13 \mathrm{MFI}$ & $24.9 \pm 11.42 \mathrm{MFI}$ \\
\hline
\end{tabular}

MFI - mean fluorescence intensity.
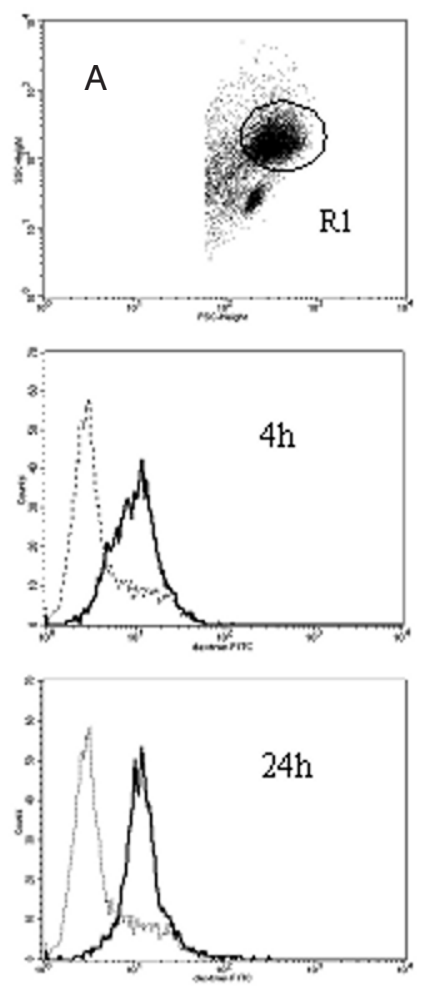
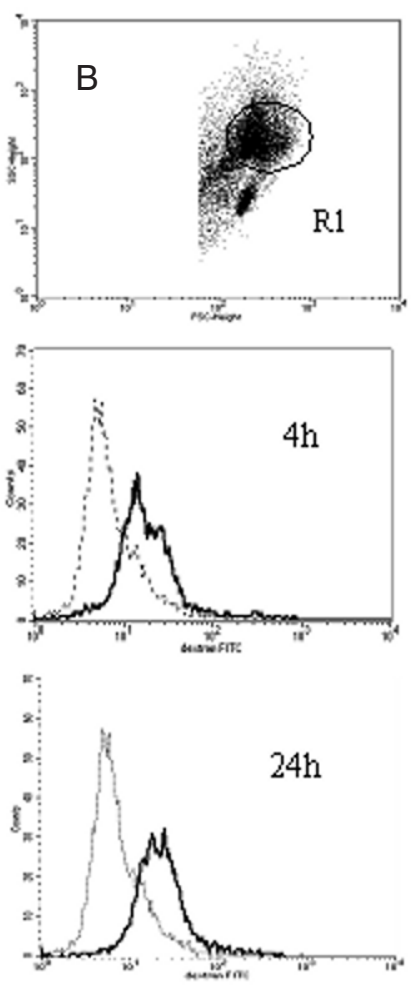
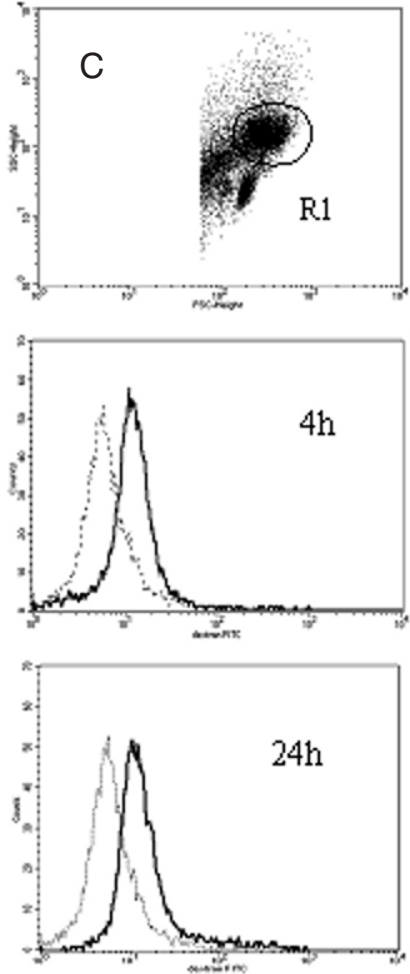

Fig. 4. Phagocytosis of FITC-dextran particles by immature DCs generated from representative patients in: A-AutoS-SC, B - AlloS-SC and C - HA-SC, after 4 and $24 \mathrm{~h}$ of incubation. Dotted line: control cells incubated at $4^{\circ} \mathrm{C}$, continuous line: cells incubated at $37^{\circ} \mathrm{C}$. Histograms correspond to the gated cells from region R1 and presented mean fluorescent intensity of FITC-dextran and cell counts.

IL-10 level correlated slightly negatively with the percentage of $\mathrm{AV}^{+} / \mathrm{PI}^{-}$cells $(\mathrm{R}=-0.60, \mathrm{p}=0.11)$ and non-significantly positively with the percentage of $\mathrm{AV}^{+} / \mathrm{PI}^{+}$ cells $(\mathrm{R}=0.57, \mathrm{p}=0.14)$. There were no significant correlations after $96 \mathrm{~h}$ of culture with autologous serum supplementation.

\section{Engulfment of FITC-dextran by generated immature DCs}

To test the phagocytic function of immature DCs generated in the above three culture systems, we evaluated the uptake of FITC-dextran by DCs using flow cytometry. The results are presented as the mean fluorescence intensity of dextran-positive cells and are shown in Table 3. The flow cytometric analysis of FITC-dextran engulfment by generated cells is shown in Fig. 4. In all the cultures we found a significantly $(\mathrm{p}<0.001)$ higher expression of FITC-dextran in cultured cells after 4 and $24 \mathrm{~h}$ of incubation than in control cells incu- bated at $4{ }^{\circ} \mathrm{C}$. We also noted that the expression of FITC-dextran after 4 and $24 \mathrm{~h}$ of incubation was significantly $(\mathrm{p}<0.05)$ higher in the cultures supplemented with autologous and allogenic serum than in the HA-SC. There were no significant differences between cells derived from autologous and AlloS-SCs in FITC-dextran expression.

\section{Immunophenotype of generated DCs}

The generated DCs were divided into two groups according to the expressions of leukocyte-monocyte-specific markers: double-positive cells $\left(\mathrm{CD}^{4} 5^{+} / \mathrm{CD} 14^{+}\right)$, which did not lose their monocytic attribute during the cultures, and $\mathrm{CD} 45^{+} / \mathrm{CD} 14^{-}$cells, which appeared to lose their monocytic feature and turn into DCs. In all the cultures we observed low percentages of $\mathrm{CD} 45^{+} / \mathrm{CD} 14^{+}$cells and high percentages of $\mathrm{CD} 45^{+} /$ $/ \mathrm{CD} 14^{-}$cells. We did not find any significant differences 

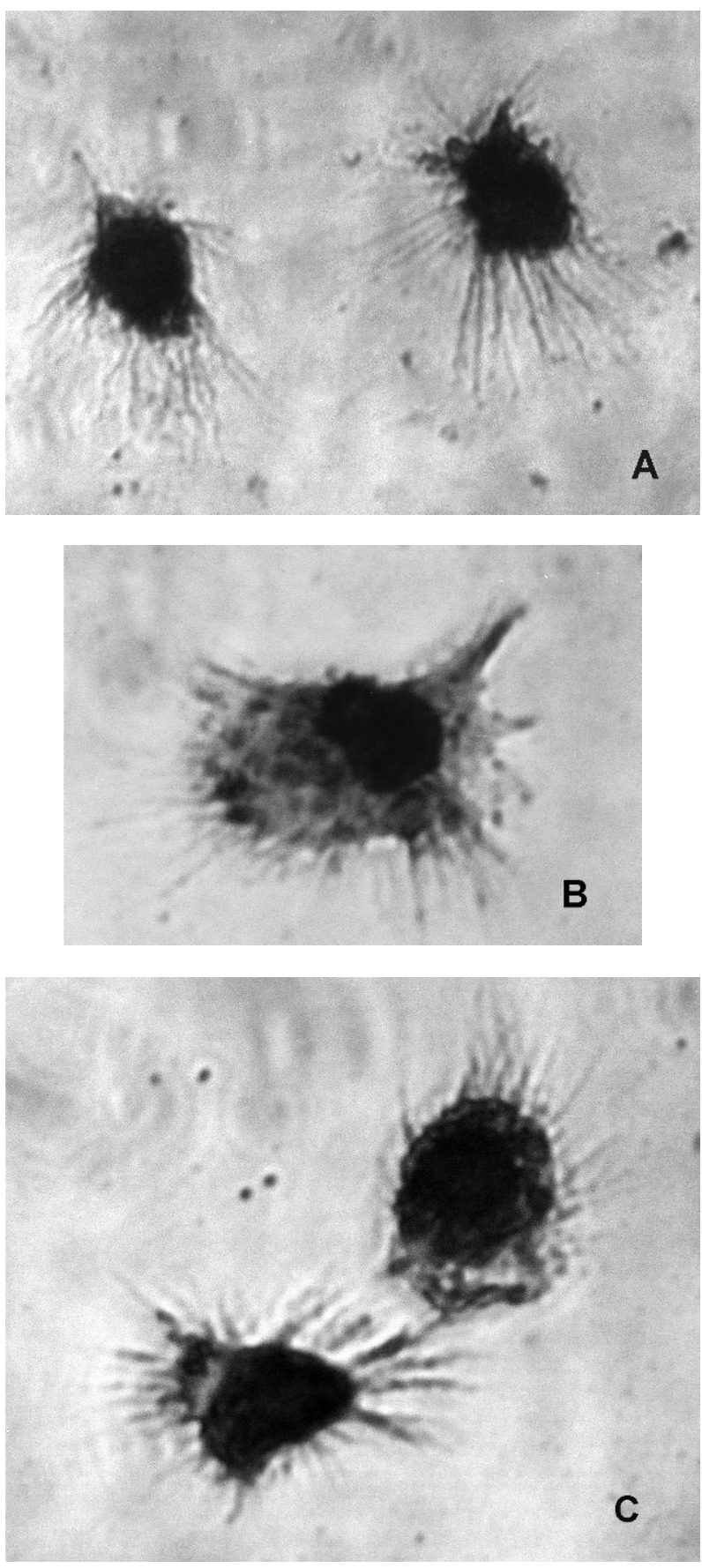

Fig. 5. Morphology of generated mature DCs in culture: A - supplemented with $10 \%$ autologous serum; B $-10 \%$ allogenic serum; C $-2 \%$ human albumin. The cells were stained by the May-Grünwald Giemsa method.

in the examined cell populations and in CD14 antigen expression in all the cultures.

In all the cultures we observed cells with typical DC morphology (Fig. 5). According to the expression of CD1a antigen, we recognized semi-mature DCs as $\mathrm{CD}^{2} 3^{+} / \mathrm{CD}^{+}{ }^{+} / \mathrm{HLA}^{-\mathrm{DR}^{+}}$cells and mature DCs as $\mathrm{CD} 83^{+} / \mathrm{CD} 1 \mathrm{a}^{-} / \mathrm{HLA}-\mathrm{DR}^{+}$cells $[36,52]$. The percentage of semi-mature DCs and of CD83 expression was lowest in the culture supplemented with $2 \%$ human albumin. Moreover, we found a significantly higher percentage of $\mathrm{CD} 3^{+} / \mathrm{CD} 1 \mathrm{a}^{+} / \mathrm{HLA}-\mathrm{DR}{ }^{+}$cells and a significantly higher expression of CD83 antigen in the culture supplemented with autologous serum than in the culture with human albumin.

We also divided the generated DCs according to the expressions of co-stimulatory molecules into $\mathrm{CD}^{+} 0^{+} /$ $/ \mathrm{CD}^{2} 6^{+} / \mathrm{HLA}^{-D R}{ }^{+}$cells and $\mathrm{CD} 80^{+} / \mathrm{CD} 86^{-} / \mathrm{HLA}^{-\mathrm{DR}^{+}}$ cells [11]. There were no differences among all the cultures in the percentages of these cells. A small population of $\mathrm{CD} 80^{-} / \mathrm{CD} 86^{+} / \mathrm{HLA}-\mathrm{DR}^{+}$cells in all the examined microenvironments was observed in only one patient (no. 3). A significantly $(\mathrm{p}<0.001)$ higher expression of CD86 antigen was observed on cells from AutoS-SC and from AlloS-SC compared with cells from HA-SC. The immunophenotype analyses of the generated DCs are presented in Table 4.

\section{Comparison of patients' clinical stage and immuno- phenotype of generated DCs}

In the culture supplemented with autologous serum we observed a significantly $(p<0.001)$ lower expression of CD14 antigen on DCs generated from the subjects in earlier stages than from those with advanced stages of disease. In the patients with localized lung cancer, the expressions of the HLA-DR and CD86 antigens were non-significantly higher than in the patients with advanced disease. CD86 antigen expression significantly positively $(\mathrm{R}=0.67, \mathrm{p}<0.05)$ correlated with IL-10 level.

Dendritic cells generated in AlloS-SC from patients with earlier stages of lung cancer were characterized by a significantly $(p<0.05)$ higher expression of HLA-DR and a significantly $(\mathrm{p}<0.05)$ lower expression of CD80 antigens than DCs generated from patients with advanced disease. We also found a non-significantly higher expression of CD14 antigen on DCs from patients with advanced stages than from those with localized lung cancer. Interestingly, in the culture supplemented with human albumin, the expression of CD14 antigen was also non-significantly higher in patients with advanced stages than in patients with earlier stages of the disease.

\section{DISCUSSION}

Currently, monocyte-derived DCs are becoming widely used as cell vaccines for cancer treatment $[10,26$, $38,49]$. The requirement for optimized and standardized protocols for the generation of DCs on a large scale has led to the description of several protocols $[2,17,21$, $33,34,49]$. In many clinical studies, autologous plasma, fetal calf serum (FCS), allogenic AB plasma, and human albumin were used as serum or protein components to support the generation of DCs [2, 12, 21,26]. The use of FCS in cultures to prepare DCs precludes their practical application, because FCS contains xenogenic proteins 
Table 4. Immunophenotype analysis of DCs generated in different culture microenvironments

\begin{tabular}{|c|c|c|c|}
\hline Immunophenotype of DCs (\%) & $10 \%$ Autologous serum & $10 \%$ Allogenic serum & $2 \%$ Human albumin \\
\hline $\mathrm{CD} 45^{+} / \mathrm{CD} 14^{-}$ & $81.9 \pm 18.13$ & $84.82 \pm 13.04$ & $78.74 \pm 17.73$ \\
\hline $\mathrm{CD} 45^{+} / \mathrm{CD} 14^{+}$ & $13.84 \pm 15.7$ & $12.33 \pm 11.9$ & $17.8 \pm 16.8$ \\
\hline $\mathrm{CD} 83^{+} / \mathrm{CD} 1 \mathrm{a}^{+}$ & $52.69 \pm 41.01$ & $46.27 \pm 38.58$ & $64.03 \pm 32.86$ \\
\hline $\mathrm{HLA}-\mathrm{DR}^{+}$cells among $\mathrm{CD} 83^{+} / \mathrm{CD} 1 \mathrm{a}^{+} \mathrm{DCs}$ & $98.53 \pm 2.51$ & $97.46 \pm 4.26$ & $90.25 \pm 25.01$ \\
\hline $\mathrm{CD} 83^{+} / \mathrm{CD} 1 \mathrm{a}^{-}$ & $35.81 \pm 42.64$ & $37.19 \pm 43.1$ & $29.17 \pm 35.12$ \\
\hline $\mathrm{HLA}^{-\mathrm{DR}^{+}}$cells among $\mathrm{CD} 83^{+} / \mathrm{CD} \mathrm{a}^{-}$ & $87.56 \pm 18.3$ & $91.51 \pm 10.78$ & $83.29 \pm 21.11$ \\
\hline $\mathrm{CD} 80^{+} / \mathrm{CD} 86^{+}$ & $82.82 \pm 16.66$ & $87.76 \pm 13.21$ & $80.66 \pm 23.14$ \\
\hline $\mathrm{HLA}-\mathrm{DR}^{+}$cells among $\mathrm{CD} 80^{+} / \mathrm{CD} 86^{+}$ & $86.73 \pm 17.37$ & $81.31 \pm 22.04$ & $86.62 \pm 21.73$ \\
\hline $\mathrm{CD} 80^{+} / \mathrm{CD} 86^{-}$ & $10.28 \pm 14.31$ & $5.29 \pm 8.04$ & $15.88 \pm 23.66$ \\
\hline 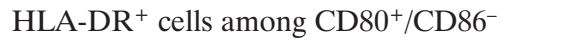 & $72.25 \pm 28.79$ & $71.79 \pm 8.04$ & $64.41 \pm 35.96$ \\
\hline
\end{tabular}

and other substances which may affect the function of DCs [26]. It is possible to use allogenic human plasma, but this raises the possibility of the transmission of infectious pathogens [21]. It has been proposed that human albumin is a kind of non-antigen culture substrate and can provide the "clearest" culture microenvironment, but one that is destitute of natural growth factors [2]. These limitations suggest that autologous plasma or serum would be a less hazardous choice for DCs generation $[12,34]$. Of course, this situation is suitable for healthy volunteers. Unfortunately, there is still insufficient information about the influence of serum from cancer patients on DCs generation from $\mathrm{CD} 14^{+}$monocytes. The active tumor-derived factors in patients' serum could impair monocytes, which might result in their abrogated differentiation into DCs in vitro $[1,22$, $31,35,40]$. The questions that then arise are whether tumors affect DCs generation and whether it is possible to reverse the restraining effect of the tumor microenvironment under in vitro conditions. To answer the questions, the aim of this study was to verify the ability to generate DCs from NSCLC-bearing patients in cultures supplemented with autologous serum, allogenic serum, and human albumin.

In this study we first tried to evaluate the fate of cultured monocytes and the induction of apoptosis on early differentiated cells. It is known that the induction of apoptosis does not occur only by direct contact with tumor cells $[23,46]$. It has been demonstrated that murine DCs treated with supernatants from tumor cell lines undergo apoptosis [46]. By combining AV, which was shown [43] to have a high affinity for phosphatidylserine, with PI we discriminated between early apoptotic cells $\left(\mathrm{AV}^{+} / \mathrm{PI}^{-}\right)$, late apoptotic cells and necrotic cells $\left(\mathrm{AV}^{+} / \mathrm{PI}^{+}\right)$, and death cells $\left(\mathrm{AV}^{-} / \mathrm{PI}^{+}\right)$ among the mononuclear cells in different culture microenvironments. We found that the highest percentage of $\mathrm{AV}^{+}$cells as well as the highest percentages of $\mathrm{AV}^{+} / \mathrm{PI}^{+}$and $\mathrm{AV}^{-} / \mathrm{PI}^{+}$cells were in those cultured for $48 \mathrm{~h}$ in human albumin. The highest percentages of apoptotic and necrotic cells were also detected after 96 $\mathrm{h}$ in the aforementioned cultures' microenvironments. Moreover, the highest percentage of $\mathrm{CD} 1 \mathrm{a}^{+} / \mathrm{CD} 14^{-}$ cells was found in the HA-SC cells. Unexpectedly, this pattern also appeared when we compared the subtypes of cells from AutoS-SC from patients in different stages of lung cancer. The percentages of $\mathrm{AV}^{+}$cells as well as the percentage of $\mathrm{CD} 1 \mathrm{a}^{+} / \mathrm{CD} 14^{-}$cells were highest in patients with early stages of lung cancer. We noted negative correlation between the percentages of $\mathrm{CD} 1 \mathrm{a}^{+} / \mathrm{CD} 14^{-}$and $\mathrm{AV}^{+} / \mathrm{PI}^{-}$cells as well as negative correlation between patients' leukocytosis and the percentages of the above cells.

It is known that monocytes lose their CD14 antigen expression during their differentiation into DCs and turn into a CD1a ${ }^{+} / \mathrm{CD} 14^{-}$cell population $[5,26,34]$. In our experiment schedule we found a significantly decreasing expression of CD14 antigen in all the performed cultures, but most of all in the HA-SCs. In connection with the apoptosis levels in the human albumin culture after 48 and $96 \mathrm{~h}$, we can suggest that the decrease in CD14 antigen expression is caused by the cells dying rather than their differentiation into immature DCs. CD14 antigen could be peeled off by apoptotic cells. This could be confirmed by results obtained in cultures performed with autologous or allogenic serum supplementation. In the aforementioned culture conditions we found lower percentages of apoptotic and necrotic cells as well as a higher expression of CD14 antigen compared with the HA-SCs. On the other hand, Avila-Moreno et al. [3] found that soluble factors from lung cancer cell lines caused an increase in the expression of myelomonocytic markers and altered the differentiation of monocytes in vitro from DCs to macrophages. In our study we also observed macrophage-like cells in AutoS-SC and AlloS-SC, but the percentage of these cells was very small. The results presented here let us speculate that autologous serum, in the case of lung cancer, provides a better culture microenvironment for the generation of autologous cells, which seem to be prevented from early apoptosis.

The cause of this phenomenon remains unclear. It has been shown repeatedly that factors which possess a strong inhibitory capacity can be detected in the serum of cancer-bearing patients [22, 23, 29]. Some trials have been carried with tumor culture supernatants (TSN). Kiertscher et al. [23] have shown a reduced capacity to produce IL-12 by DCs generated with TSN supplementation. However, Marten et al. [27] have shown the strong stimulatory activity of DCs generated with 
patient-derived CA-19-9-antigen-containing serum. The HA-SCs are a clear environment for DCs generation, but it seems to be devoid of important cell viability factors. Interestingly, Araki et al. [2] generated efficient DCs from $\mathrm{CD}_{14}{ }^{+}$monocytes of healthy volunteers in the presence of human albumin. It is widely known that many cytokines or immunosuppressive cancer-derived factors detected in the serum of cancer patients interfered in many ways with each stage of the generation of DCs $[7,14,16,22,29,35,39]$. It has been suggested that IL-10 is the most important inhibitory factor responsible for impaired immune responses in the peripheral blood of cancer-bearing patients [7, 13, 14]. A variety of human tumors produce IL-10. The mRNA for IL-10 was detected in metastatic melanoma and renal, ovarian, and basal cell carcinomas [25, 32]. We have also shown that the level of IL-10 detected in patients' serum positively correlated with the percentage of $\mathrm{CD} 1 \mathrm{a}^{+} / \mathrm{CD} 14^{-}$ cells and $\mathrm{AV}^{+} / \mathrm{PI}^{+}$cells in AutoS-SC.

It should be noted that in most cancer patients the inflammation process coexists with the development of neoplasm, which could result in a greater release of immunomodulatory factors [9]. Our results suggest that the progression of lung cancer had a beneficial impact on the vitality of mononuclear cells in short-terminated cultures. In light of the present results, the restraining effect of tumor-derived factors in autologous serum from NSCLC patients appears to be overestimated. We propose that generalized lung cancer does not exert as strong an inhibitory pressure on autologous DCs generation as suspected up to now.

Some literature data concerned the generation of DCs from patients with advanced cancer [26, 29, 33, 51]. Menetrier-Caux et al. [29] demonstrated that tumor cells produce factors which could significantly inhibit the differentiation of hematopoietic precursors and, in turn, DCs generation. It has been shown repeatedly that the expressions of CD83 and CD86, human DC-related markers, decreased in DCs cultures co-incubated with supernatant from human tumor cells $[7,13]$. In this study we estimated the presence of mature $\mathrm{CD} 83^{+} / \mathrm{CD} 1 \mathrm{a}^{-}$DCs with co-expression of costimulatory molecules in all the cultures. Interestingly, the highest expression of CD83 antigen was found in AutoS-SC. These findings are contrary to those of Kiertscher et al. [23], who had demonstrated that tumor culture supernatants effectively suppress the function of monocyteand stem cell-derived DCs. Onishi et al. [31] showed that monocyte-derived DCs from cancer patients possessed weaker antigen-presenting abilities than those generated from healthy volunteers. In our study we found that immature DCs generated in all the cultures show phagocytic activity measured by dextran particle engulfment. When we compared the culture microenvironments we found the highest level of FITC-dextran fluorescence in cells generated with autologous and allogenic serum supplementation. This confirms the above thesis about the beneficial influence of autologous and allogenic serum on DCs generation.
To sum up, we have documented the course of the apoptosis, phagocytic ability, and the immunophenotype of DCs generated in different culture microenvironments. First of all we can conclude that the kind of culture supplementation had a great impact on the apoptosis of generated DCs. It could also influence the yield of monocyte-derived DCs, which should be examined in a further study. Secondly, we can confirm that autologous and allogenic serums provide a suitable microenvironment for the generation of autologous DCs from NSCLC patients. Of course, further studies should expand upon lymphocytic stimulation by generated DCs, which could provide an important insight into the stimulatory activity of DCs. Also, the efficacy of DCs generation from PBMCs of lung cancer patients should be tested using serum-free media available commercially, such as CellGro DC. The choice of culture supplementation for DCs generation is still unsolved and further studies should be undertaken.

Acknowledgment: This study was supported by the State Committee for Scientific Research (KBN, Warsaw, Poland), grant no. 2 P05B 12027.

\section{REFERENCES}

1. Aalamian M., Tourkova I. L., Chatta G. S., Lilja H., Huland E., Huland H., Shurin G. V. and Shurin M. R. (2003): Inhibition of dendropoiesis by tumor derived and purified prostate specific antigen. J. Urol., 170, 2026-2030.

2. Araki H., Katayama N., Mitani H., Suzuki H., Nishikawa H., Masuya M., Ikuta Y., Hoshino N., Miyashita H., Nishii K., Minami N. and Shiku H. (2001): Efficient ex vivo generation of dendritic cells from CD14+ blood monocytes in the presence of human serum albumin for use in clinical vaccine trials. Br. J. Haematol., 114, 681-689.

3. Avila-Moreno F., Lopez-Gonzalez J. S., Galindo-Rodriguez G., Prado-Garcia H., Bajana S. and Sanchez-Torres C. (2006): Lung squamous cell carcinoma and adenocarcinoma cell lines use different mediators to induce comparable phenotypic and functional changes in human monocyte-derived dendritic cells. Cancer Immunol. Immunother., 55, 599-611.

4. Beadsmoore C. J. and Screaton N. J. (2003): Classification, staging and prognosis of lung cancer. Eur. J. Radiol., 45, 8-17.

5. Bohnenkamp H. R., Burchell J. M., Taylor-Papadimitriou J. and Noll T. (2004): Apoptosis of monocytes and the influence on yield of monocyte-derived dendritic cells. J. Immunol. Methods, 294, 67-80.

6. Boon T. and Van den Eynde B. (2003): Tumour immunology. Curr. Opin. Immunol., 15, 129-130.

7. Buelens C., Verhasselt V., De Groote D., Thielemans K., Goldman M. and Willems F. (1997): Interleukin 10 prevents the generation of dendritic cells from human peripheral blood mononuclear cells cultured with interleukin 4 and granulocyte/macrophage-colony-stimulating factor. Eur. J. Immunol., 27, 756-762.

8. Chouaib S., Asselin-Paturel C., Mami-Chouaib F., Caignard A. and Blay J. Y. (1997): The host-tumor immune conflict: from immunosuppression to resistance and destruction. Immunol. Today, 18, 493-497.

9. Coussens L. M. and Werb Z. (2002): Inflammation and cancer. Nature, 420: 860-867. 
10. Cranmer L. D., Trevor K. T. and Hersh E. M. (2004): Clinical applications of dendritic cells vaccination in the treatment of cancer. Cancer Immunol. Immunother., 53, 275-306.

11. Dilioglou S., Cruse J. M. and Lewis R. E. (2003): Function of CD80 and CD86 on monocyte- and stem cell-derived dendritic cells. Exp. Mol. Pathol., 75, 217-227.

12. Eljaafari A., Duperrier K., Mazet S., Bardin C., Bernaud J., Durand B., Gebuhrer L., Betuel H. and Rigal D. (1998): Generation of stable monocyte-derived dendritic cells in the presence of high concentrations of homologous or autologous serum: influence of extra-cellular $\mathrm{pH}$. Hum. Immunol., 59, 625-634.

13. Enk A. H., Angeloni V. L., Udey M. C. and Katz S. I. (1993): Inhibition of Langerhans cell antigen-presenting function by IL-10. A role of IL-10 in induction of tolerance. J. Immunol., 151, 2390-2398.

14. Faulkner L., Buchan G. and Baird M. (2000): Interleukin-10 does not affect phagocytosis of particulate antigen by bone marrow-derived dendritic cells but does impair antigen presentation. Immunology, 99, 523-531.

15. Foss F. (2002): Immunologic mechanisms of antitumor activity. Semin. Oncol., 29 (suppl. 7), 5-11.

16. Gabrilovich D. I., Chen H. L., Girgis K. R., Cunningham H. T., Meny G. M., Nadaf S., Kavanaugh D. and Carbone D. P. (1999): Production of vascular endothelial growth factor by human tumors inhibits the functional maturation of dendritic cells. Nat. Med., 2, 1096-1103.

17. Gatti E. and Pierre P. (2003): Understanding of cell biology of antigen presentation: the dendritic cell contribution. Curr. Opin. Cell. Biol., 15, 468-473.

18. Gilboa E. (1999): How tumors escape immune destruction and what we can do about it. Cancer Immunol. Immunother., 48, 382-385.

19. Hespanhol V., Queiroga H., Magalhaes A., Santos A.R., Coelho M. and Marques A. (1995): Survival predictors in advanced non-small lung cancer. Lung Cancer, 13, 253-267.

20. Jager E., Jager D. and Knuth A. (2002): Clinical cancer vaccine trials. Curr. Opin. Immunol., 14, 178-182

21. Jakobsen M. A., Moller B. K. and Lillevang S. T. (2004): Serum concentration of the growth medium markedly affects monocyte-derived dendritic cells' phenotype, cytokine production profile and capacities to stimulate in MLR. Scan. J. Immunol., 60, 584-491.

22. Kacani L., Wurm M., Schennach H., Braun I., Andrle J. and Sprinzl G. M. (2003): Immunosuppressive effects of soluble factors secreted by head and neck squamous cell carcinoma on dendritic cells and $\mathrm{T}$ lymphocytes. Oral Oncol., 39, 672-679.

23. Kiertscher S. M., Luo J., Dubinett S. M. and Roth M. D. (2000): Tumors promote altered maturation and early apoptosis of monocyte-derived dendritic cells. J. Immunol., 164, 1269-1276.

24. Kim D. W., Shyr Y., Shaktour B., Akerley W., Johnson D. H. and Choy H. (2005): Long term follow up and analysis of long term survivors in patients treated with paclitaxel-based concurrent chemo/radiation therapy for locally advanced non-small cell lung cancer. Lung Cancer, 50, 235-245.

25. Lattime E. C., Mastrangelo M. J., Bagasra O., Li W. and Berd D. (1995): Expression of cytokine mRNA in human melanoma tissues. Cancer Immunol. Immunother., 41, 151-156.

26. Lotze M. T. and Thomas A. W. (2001): Dendritic cells. Second edition. Academic Press, United Kingdom.

27. Marten A., Ziske C., Schottker B., Renoth S., Weineck S.,
Buttgereit P., Schakowski F., Klingmuller D., Scheffold C., Rucker A., Sauerbruch T. and Schmidt-Wolf I. (2000): Increase in the immunostimulatory effect of dendritic cells by pulsing with serum derived from pancreatic and colorectal cancer patients. Int. J. Colorectal Dis., 15, 197-205.

28. Meidenbauer N., Andreesen R. and Mackensen A. (2001): Dendritic cells for specific cancer immunotherapy. Biol. Chem., 382, 507-520.

29. Menetrier-Caux C., Montmain G., Dieu M. C., Bain C., Favrot M. C., Caux C. and Blay J. Y. (1998): Inhibition of the differentiation of dendritic cells from CD34+ precursors by tumor cells: role of IL- 6 and macrophage-colony-stimulating factor. Blood, 92, 4778-4791.

30. Offringa R., van der Burg S. H., Ossendorp F., Toes R. E. and Melief C. J. (2000) Design and evaluation of antigen-specific vaccination strategies against cancer. Curr. Opin. Immunol., 12, 576-582.

31. Onishi H., Morisaki T., Baba E., Kuga H., Kuroki H., Matsumoto K., Tanaka M. and Katano M. (2002): Dysfunctional and short-lived subsets in monocyte-derived dendritic cells from patients with advanced cancer. Clinical Immunol., 105, 286-295.

32. Paglia P. and Guzman C. A. (1998): Keeping the immune system alerted against cancer. Cancer Immunol. Immunother., 46, 88-92.

33. Pedersen A. E., Thorn M., Gad M., Walter M. R., Johnsen H. E., Gaarsdal E., Nikolajsen K., Buuss S., Claesson M. H. and Svane I. M. (2005): Phenotypic and functional characterisation of clinical grade dendritic cells generated from patients with advanced breast cancer for therapeutic vaccination. Scan. J. Immunol., 61, 147-156.

34. Pietschmann P., Stockl J., Draxler S., Majdic O. and Knapp W. (2000): Functional and phenotypic characteristic of DC generated in human plasma supplemented medium. Scan. J. Immunol., 51, 377-383.

35. Pinzon-Charry A., Maxwell T. and Lopez J. A. (2005): Dendritic cell dysfunction in cancer: a mechanism for immunosuppression. Immunol. Cell. Biol., 83, 451-461.

36. Romani N., Reider D., Heuer M., Ebner S., Kampgen E., Eibl B., Niederwieser D. and Schuler G. (1996): Generation of mature dendritic cells from human blood. An improved method with special regard to clinical applicability. J. Immunol. Methods, 196, 137-51

37. Saito H., Tsujitani S., Ikeguchi M., Maeta M. and Kaibara N. (1998): Relationship between the expression of vascular endothelial growth factor and the density of dendritic cells in gastric adenocarcinoma tissue. Br. J. Cancer, 78, 1573-1577.

38. Schuler G., Schuler-Thurner B. and Steinman R. M. (2003): The use of dendritic cells in cancer immunotherapy. Curr. Opin. Immunol., 15, 138-147

39. Shurin G., Shurin M. R., Bykovskaia S., Shogan J., Lotze M. T. and Barksdale E. M. Jr. (2001): Neuroblastoma-derived gangliosides inhibit dendritic cell generation and function. Cancer Res., 61, 363-369.

40. Sietsma H., Nijhof W., Dontje B., Vellenga E., Kamps W. A. and Kok J. W. (1998): Inhibition of hemopoiesis in vitro by neuroblastoma-derived gangliosides. Cancer Res., 58, 4840-4844.

41. Soruri A. and Zwirner J. (2005): Dendritic cells: limited potential in immunotherapy. Int. J. Biochem. Cell. Biol., 37, 241-245.

42. Troy A., Davidson P., Atkinson C. and Hart D. (1998): Phenotypic characterisation of the dendritic cell infiltrate in prostate cancer. J. Urol., 160, 214-219. 
43. Van Engeland M., Nieland L. J., Ramaekers F. C., Schutte B. and Reutelingsperger C. (1998): Annexin V-affinity assay: a review on an apoptosis detection system based on phosphatidylserine exposure. Cytometry, 31, 1-9.

44. Vermes I., Haanen C., Steffens-Nakken H. and Reutelingsperger C. (1995): A novel assay for apoptosis. Flow cytometric detection of phosphatidylserine expression on early apoptotic cells using fluorescein labeled Annexin V. J. Immunol. Methods, 184, 39-51.

45. Vicari A., Caux C. and Trinchieri G. (2002): Tumor escape form immune surveillance through dendritic cell inactivation. Semin. Cancer Biol., 12, 33-42.

46. Walker P. R., Saas P. and Dietrich P. Y. (1998): Tumor expression of Fas ligand (CD95L) and the consequences. Curr. Opin. Immunol., 10, 564-572.

47. Weynants P., Marchandise F. X. and Sibille Y. (1997): Pulmonary perspective: immunology in diagnosis and treatment of lung cancer. Eur. Respir. J., 10, 1703-1719

48. Wisnivesky J. P., Henschke C., McGinn T. and Iannuzzi M.
C. (2005): Prognosis of Stage II non-small cell lung cancer according to tumor and nodal status at diagnosis. Lung Cancer, 49, 181-186.

49. Yannelli J. R., Sturgill J., Foody T. and Hirschowitz E. (2005): The large scale generation of dendritic cells for the immunization of patients with non-small cell lung cancer (NSCLC). Lung Cancer, 47, 337-350.

50. Yano T., Sugio K., Yamazaki K., Kase S., Yamaguchi M., Ondo K., Yoshino I. and Sugimachi K. (1999): Postoperative adjuvant adoptive immunotherapy with lymph node-LAK cells and IL-2 for pathologic stage I non-small cell lung cancer. Lung Cancer, 26, 143-148.

51. Zavadova E., Savary C.A., Templin S., Verschraegen C. F. and Freedman R. S. (2001): Maturation of dendritic cells from ovarian cancer patients. Cancer Chemother. Pharmacol., 48, 289-296.

52. Zhou L. J and Tedder T. F. (1996): CD14+ blood monocytes can differentiate into functionally $\mathrm{CD} 83^{+}$dendritic cells. Proc. Natl. Acad. Sci. USA, 93, 2588-2592. 